\title{
Determinants of diabetic retinopathy in Southwest Ethiopia: a facility-based case- control study
}

\author{
Dugasa Garoma ${ }^{1}$, Hailu Merga ${ }^{2^{*}}$ and Desta Hiko ${ }^{2}$
}

\begin{abstract}
Background: Diabetic Retinopathy is one of the serious complications patients' diabetic patients suffer from. Little is known about which risk factors are associated with this complication. The aim of this study was therefore to identify determinants of Diabetic Retinopathy in Jimma University Medical Center.

Methods: A facility-based case-control study was conducted. Cases were Diabetic patients with diabetic retinopathy and who were on follow up at the Jimma University Medical Center while controls were Diabetic patients but free of diabetic retinopathy and who were on follow up at the Jimma University Medical Center. Cases and controls were identified and 311 of them were recruited using systematic random sampling. Data were entered into the Epi-Data version 4.1 and analyzed using SPSS Version 20. Binary Logistic regression analysis was conducted to identify determinants of diabetic retinopathy.

Result: A total of 106 cases and 205 controls diabetic participated in the study. Being $\geq 60$ years of age ( $\mathrm{AOR}=5.04,95 \% \mathrm{Cl}$ : 1.83,13.87),being illiterate ( $A O R=7.17,95 \%$ Cl: 2.61,19.7), poor adherence to medication ( $A O R=3: 95 \%$ Cl: 1.29,6.95), having high systolic blood pressure (AOR $=3.38: 95 \% \mathrm{Cl}: 1.26,9.05)$, having family history of Diabetes Mellitus (AOR $=3.95: 95 \%$ Cl: 1.64, 9.54), having other micro vascular complications ( $\mathrm{AOR}=3.76,95 \% \mathrm{Cl}$ : 1.33,10.66), poor glycemic control $(\mathrm{AOR}=9.08,95 \% \mathrm{Cl}$ : 3.7,22.29), poor cholesterol control ( $\mathrm{AOR}=0.21,95 \% \mathrm{Cl}$ : 0.08,0.51) and being anaemic ( $\mathrm{AOR}=2.8,95 \% \mathrm{Cl}: 1.05,7.47)$ were the independent determinants of diabetic retinopathy.

Conclusion: This study found that poor adherence to medication, being at the age of 60 years and above, being illiterate patients, having high systolic blood pressure, having a family history of Diabetes Mellitus, having other micro vascular complication, poor glycemic control, poor cholesterol control and being anemic patient were the independent determinants of diabetic retinopathy. Therefore, more attention should be given to older age and illiterate patients. Giving more emphasis for patients poorly adhered to anti-diabetic medications and giving advice for diabetic patients with high systolic blood pressure to follow their blood pressure regularly are also vital. Diabetic patients should also control their Blood sugar and blood cholesterol levels to prevent diabetic retinopathy or reduce its further complications.
\end{abstract}

Keywords: Diabetic retinopathy, Determinants, Case control study Southwest Ethiopia

\footnotetext{
*Correspondence: hailu.merga2014@gmail.com

${ }^{2}$ Department of Epidemiology, Institute of Health, Jimma University, Jimma, Ethiopia

Full list of author information is available at the end of the article
}

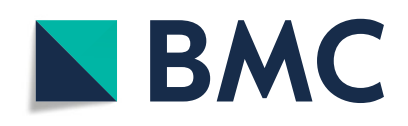

(- The Author(s). 2020 Open Access This article is licensed under a Creative Commons Attribution 4.0 International License, which permits use, sharing, adaptation, distribution and reproduction in any medium or format, as long as you give appropriate credit to the original author(s) and the source, provide a link to the Creative Commons licence, and indicate if changes were made. The images or other third party material in this article are included in the article's Creative Commons licence, unless indicated otherwise in a credit line to the material. If material is not included in the article's Creative Commons licence and your intended use is not permitted by statutory regulation or exceeds the permitted use, you will need to obtain permission directly from the copyright holder. To view a copy of this licence, visit http://creativecommons.org/licenses/by/4.0/. The Creative Commons Public Domain Dedication waiver (http://creativecommons.org/publicdomain/zero/1.0/) applies to the data made available in this article, unless otherwise stated in a credit line to the data. 


\section{Background}

Diabetic retinopathy (DR) is a neurovascular complication of both type 1 and type 2 diabetes, which strongly correlates to both the duration of diabetes and the level of glycemic control. It is the major long-term complication of diabetes and the main cause of vision impairment and vision loss. Diabetic retinopathy is a primary cause of visual injury in working-age adults [1,2].

Diabetic retinopathy is the specific micro-vascular complication of Diabetes Mellitus (DM) and affects 1 in 3 persons with DM [3]. Evidence showed that DR is responsible for $4.8 \%$ of the 37 million cases of blindness due to eye diseases throughout the world [4]. A follow up study revealed that $79.3 \%$ of individuals with type 1 and $82.6 \%$ of type 2 diabetes had evidence of ever having had a DR [5].

A Global meta-analysis study done in US, Australia, Europe and Asia reported that 1 in 3 (34.6\%) had any form of diabetic retinopathy [6]. In the 2010 world diabetes population, more than 92 million adults had any form of Diabetic Retinopathy and DR develops with time and is associated with poor control of blood sugar, blood pressure, and blood lipids [3].

WHO reported that a good controller of diabetes and hypertension significantly reduces the risk for diabetic retinopathy [7]. Major risk factors of the DR may include the length of time the patient lived with diabetes, hyperglycemia, high blood pressure, lipid disorders, pregnancy and puberty, age at diagnosis, ethnicity and genetic disorders among others. DR develops as a consequence of the long-term accumulation of damage of retinal vessels [1]. Significant systemic risk factors include hypertension and high hemoglobin, systolic blood pressure (SBP), pulse pressure, serum lipoprotein level and body mass index (BMI). Other documented risk factors are renal disease/nephropathy, genetic factors, high waist-hip ratio (abdominal obesity), upper socioeconomic status, urban residence, male gender, insulin treatment and pregnancy [8].

In Ethiopia, around 2.1 million people are suffering from diabetes, of which $4.8 \%$ of adults are living with diabetes and $39 \%$ of these 2.1 million people are additionally suffering from DR [9]. From review of the existing evidences, determinants of Diabetic Retinopathy among diabetic patients on follow up in the Ethiopian health care setups have not been well documented.. Moreover, limited studies conducted in Ethiopia were cross-sectional studies; as a result, major risk factors were not well documented to guide interventions to reduce the new occurrence and target risk factors of DR. Therefore, this study was aimed to identify determinants of Diabetic Retinopathy in Jimma University Medical Center in Southwest Ethiopia.

\section{Methods}

\section{Study setting and population}

A facility based case control study was conducted in the Jimma University Medical Center (JUMC), the specialized hospital in Southwest of Ethiopia. The study was conducted from March 10 to May 09, 2018. The Hospital is located in Jimma City, (located $335 \mathrm{~km}$ Southwest of Addis Ababa, the capital). The hospital gives health services for more than 10 million people living in Southwest Ethiopia. The hospital has chronic follow-up clinics for both pediatric and adult patients. The diabetes clinic runs twice weekly and provides integrated diabetic care for both Type 1 and Type 2 diabetics for about 70-90 patients per day. In the hospital, there were around 3020 diabetic patients who follow regularly their treatments of which 946 patients were with DR and around 1605 of the patients were free of DR.

In this study, a case was defined as a diabetic patient with any of the following characteristic lesion: micro aneurisms, or hemorrhage, or hard exudates, or venous beading and new vessels on retina (diagnosis of new vessels on retina is a confirmatory tool for physicians or ophthalmologists that a DM patient has DR as a complication while control was defined as diabetic patients free of any of the criteria mentioned for cases in the above statement $[10,11]$. The source population of the cases was all patients with DM and diagnosed with DR and visiting JUMC while the source population for controls was all patients with DM patients free of DR and visiting JUMC. All adults (above 15 years) DM patients who had no severe mental problems participated in the study while DM patients who were not volunteer to participate were excluded from the study.

\section{Sample size and sampling technique}

Sample size was determined using EpiInfo statistical software version 7 using the following assumptions of two population proportion formula for the unmatched case-control studies: high baseline diastolic blood pressure (was taken as main exposure variable as it gave maximum sample size compared to other exposure variables) [12], 5\% level of significance, $80 \%$ power, $2: 1$ control to case ratio, $9.47 \%$ expected prevalence of high baseline diastolic blood pressure among patients free of DR retinopathy (controls) and $21.1 \%$ expected prevalence of high baseline diastolic blood pressure among patients with DR (cases). As a result, 318 (106 cases and 212 controls) were considered to participate in the main study after considering $5 \%$ for non-response. Before the main study, cases $(n=946)$ and controls $(n=1605)$ were identified using the aforementioned case and control definitions. The sampling frame (list) of cases and controls was prepared systematic random sampling technique was used to select cases and controls for final data 
collection. Cases were selected from diabetic retinopathy patients and controls from free of retinopathy diabetic patients by systematic random sampling from ever enrolled diabetic patients on diabetic follow-up as a sampling frame. The kth value in the systmetaic sampling procedure for both case and control was calculated by diving each source population by the total sample size. For control the kth value was 5 and the 4 rth patient was selected by using lottery method, then data was collected from every 5 th patients starting from the 4th patient free of diabetic retinopathy by systematic random sampling. Similarly the kth value for the case was 3 from the list of 1 to $3 \mathrm{DM}$ patient, the 2nd patient was selected by using lottery method, then data was collected from every 3rd patients starting from the 2 nd patient with diabetic retinopathy by systematic random sampling.

\section{Data collection procedures}

An interviewer-administered questionnaire was used to collect data from participants using the local language (Afan Oromo language). The questionnaire was developed after reviewing different kinds of literature [7, 1217] (Additional file 1). The consistency of the questionnaire prepared in English translated into the local language (Afan Oromo) and back translating to English to check the consistency. Several medical-related data like blood pressure, cholesterol and glucose level, microvascular complications and hemoglobin level were collected from a patient's record while socio-demographic, behavioral and other medical related data were collected by interviewing patients. Two trained Bachelor degree holders nurses collected the data. One Public Health degree holder supervised the data collection process. The quality of data was maintained by conducting the following: data collectors were trained for one day on how to collect data from participants, the whole contents of the questionnaire were explained to eliminate the difference between data collectors in understanding questions and pre-test was also conducted among 16 DM patients (5\% of the sample size) in hospital outside Jimma town to ensure that the data collectors and respondents understood the questions. Accordingly, appropriate amendments were made on the questionnaire after pre-test. The data collection process was supervised and filled questionnaires were cross-checked for completeness and consistency. Finally, data were edited for possible errors, double entered using Epi-Data version 4.1 to eliminate errors that occur during data entry, and cleaned for missing values and outliers in SPSS version 20.

\section{Measurements}

Diabetic retinopathy was diagnosed by ophthalmologists using slit lamp by dilating fundus examination using $1 \%$ tropic amide eye drop and diabetic patients who were considered to have damaged retinal blood vessels diagnosed and confirmed as diabetic retinopathy [18]. Weight was measured in light closing and without shoes in kilograms $(\mathrm{kg})$ using calibrated digital weighing scale at a precision of $0.1 \mathrm{~kg}$ as per recommended but not repeated measurements. Height was measured using a stadiometer in centimeter $(\mathrm{cm})$ in an erect position that the back of the head, shoulder blades, buttocks, and heels make a contact with the backboard at a precision of 0.1 $\mathrm{cm}$ with shoes removed as per recommended but not repeated measurements. Blood pressure was measured using a mercury sphygmomanometer with a cuff deflation rate of $2 \mathrm{mmHg}$. Two measurements were taken from left arm while the participant was in sitting position. Five minutes between each measurement was maintained to take avoid measurment bias. Cholesterol level was taken from the patient's folder near to the time of data collection and if not present in the folder, $4 \mathrm{ml}$ of the whole blood sample was taken and sent to the laboratory for both cases and controls. Hemoglobin was taken from the patient's folder near to the time of data collection and if not present in the folder, $1 \mathrm{ml}$ of the whole blood sample was taken and sent to the laboratory for both cases and controls. Operational definitions. Adherence to medication was defined as "if the patients took all his/her anti-diabetic medication in last seven days before the study" while adherence to blood glucose testing at home was defined as "if the patient measured his blood glucose for at least once every week $[19,20]$ ". Alcohol consumption history was defined as "if the patient reported consumption of any type of alcoholic beverages within the past 12 months were considered as alcohol consumers [20]". Glycemic control was measured by random blood sugar. Average of the random blood sugar level of the last three records was used to define glycemic control. Any diabetic patient whose blood glucose measurement above $200 \mathrm{mg} / \mathrm{dl}$ was considered as good glycemic control while any diabetic patient whose blood glucose measurement $200 \mathrm{mg} / \mathrm{dl}$ and below was considered as poor glycemic control. Adherence to diet was assessed from report of particiapant wether he/she has followed recommended diet. If the patient followed the recommended diet forr more than 3 days in last seven days before the study period, that participant was labeled as adherent otherwise not adherent.

\section{Data analysis}

The collected data were edited, coded and entered into Epi-Data version 4.1 and then exported to SPSS 20 for analysis. Descriptive statistics (frequencies, crosstabulations and summary measures) were computed. Exposure variables associated with DR were identified using bivariate logistic regression analysis. Exposure variables with $p$-value $<0.25$ were considered for final 
multivariable logistic regression analysis using the Backward Likelihood ratio method. Crude Odds ratios (CORs) and Adjusted Odds ratios (AOR) with their respective 95\% CIs were computed for each exposure variable. $P$ value $<0.05$ was used to declare statistical significance and exposure variables with $p$-value $<0.05$ were considered as determinants of DR. Model goodness of fit was checked using the Hosmer Lemeshow test of goodness of fit $\left(\mathrm{x}^{2}=\right.$ 14.047, P-value $=>0.05(0.081)$, omnibus likelihood test $<$ $0.05(0.000)$ with $89 \%$ model accuracy.

\section{Results}

\section{Socio demographic characteristics}

A total of 311 (97.8\%) (106 cases and 205 controls) of DM patients who were on follow up in the Jimma University medical center participated in the study. The mean age ( \pm Standard deviation) for the cases and the controls were 59.08 (SD: \pm 9.25 ) and 42.42 (SD: \pm 13.95 ) respectively. About two third, $65 \%$ of the cases and $60.9 \%$ of controls, were male participants. More than half, $52 \%$ of cases and $56.6 \%$ of controls were from rural residential. The majority of the cases $(59.4 \%)$ and most of the controls (87.8\%) were literate. Of those cases, 27.4 and $72.6 \%$ were government employees and self and private businesses respectively, but from the controls 20.5 and $79.5 \%$ were government employer and self and private business respectively (Table 1 ).

\section{Behavioral characteristics}

More than half, $55.6 \%$, of cases and about two third, $63.4 \%$, of controls were adhered to have regular exercise, and $38.6 \%$ of the cases and $55.1 \%$ of the controls adhered to the medication of diabetes. History of alcohol consumption was assessed and $15 \%$ of cases and $4.8 \%$ controls consumed the alcohol. Similarly, five of the participants from cases and two from the controls had a history of smoking. Regarding meal instruction adherence, about one third (35.8\%) of cases and $62.9 \%$ controls adhered to meal instructions. From all study participants, 62 (58.5\%) of cases and 166 (80.9\%) of controls adhered to blood glucose measurement at home (Table 2).

\section{Medical history}

More than nine-tenths (93.4\%) of the cases and more than half $(60.5 \%)$ of the controls were type II diabetic patients. There was a family history of DM in $56(52.8 \%)$ of cases and 64 (31.2\%) of controls. About half (48.1\%) of the cases and less than one tenth (9.7\%) of controls had a history or diagnosed as having other microvascular complications like heart and renal diseases. In this study, 41 (38.7\%) of the cases and about one-tenth (9.3\%) of controls had systolic hypertension, whereas 49 (46.3\%) of cases and about one fourth (23\%) of controls had diastolic hypertension. The proportion of poor glycaemic control was $63.2 \%$ in cases and $20 \%$ in controls. More than half $(56.2 \%)$ of cases and more than one fourth $(27.1 \%)$ of controls had also poor serum cholesterol levels. One third (32.4\%) of cases and $8.7 \%$ of controls were anemic while $30(28.3 \%)$ of cases and 59 (28.8\%) of controls were overweight (Table 3).

Table 1 Socio demographic characteristics of diabetic patients who follow at Jimma University Medical Center, Ethiopia, 2018

\begin{tabular}{|c|c|c|c|c|c|}
\hline Variable & Category & $\begin{array}{l}\text { Cases } \\
(\boldsymbol{n}=106)\end{array}$ & $\begin{array}{l}\text { Controls } \\
(\boldsymbol{n}=205)\end{array}$ & $\begin{array}{l}\text { COR } \\
(95 \% \mathrm{Cl})\end{array}$ & P-Value \\
\hline$\overline{\text { Age }}$ & $\begin{array}{l}<60 \text { years } \\
\geq 60 \text { years }\end{array}$ & $\begin{array}{l}48(45.3 \%) \\
58(54.7 \%)\end{array}$ & $\begin{array}{l}177(86.3 \%) \\
28(13.7 \%)\end{array}$ & $\begin{array}{l}1 \\
7.63(4.39,13.27)\end{array}$ & $<0.001$ \\
\hline Residence & $\begin{array}{l}\text { Urban } \\
\text { Rural }\end{array}$ & $\begin{array}{l}51(48 \%) \\
55(52 \%)\end{array}$ & $\begin{array}{l}89(43.4 \%) \\
116(56.6 \%)\end{array}$ & $\begin{array}{l}1 \\
0.82(0.51,1.32)\end{array}$ & 0.43 \\
\hline Education level & $\begin{array}{l}\text { Illiterate } \\
\text { Literate }\end{array}$ & $\begin{array}{l}43(40.6 \%) \\
63(59.4 \%)\end{array}$ & $\begin{array}{l}25(12.2 \%) \\
180(87.8 \%)\end{array}$ & $\begin{array}{l}4.91(2.77,8.69) \\
1\end{array}$ & $<0.001$ \\
\hline Occupation & $\begin{array}{l}\text { Government employee } \\
\text { Self and private business }\end{array}$ & $\begin{array}{l}29(27.4 \%) \\
77(72.6 \%)\end{array}$ & $\begin{array}{l}42(20.5 \%) \\
163(79.5 \%)\end{array}$ & $\begin{array}{l}1 \\
0.68(0.39,1.18)\end{array}$ & 0.173 \\
\hline Family's Monthly Income & $\begin{array}{l}<3061 \text { ETB } \\
\geq 3061 \text { ETB }\end{array}$ & $\begin{array}{l}76(71.7 \%) \\
30(28.3 \%)\end{array}$ & $\begin{array}{l}117(57.1 \%) \\
88(42.9 \%)\end{array}$ & $\begin{array}{l}1.90(1.15,3.15) \\
1\end{array}$ & 0.012 \\
\hline Sex & $\begin{array}{l}\text { Male } \\
\text { Female }\end{array}$ & $\begin{array}{l}69(65 \%) \\
37(35 \%)\end{array}$ & $\begin{array}{l}125(60.9 \%) \\
80(39.1 \%)\end{array}$ & $\begin{array}{l}0.83(0.51,1.36) \\
1\end{array}$ & 0.477 \\
\hline Marital status & $\begin{array}{l}\text { In Union } \\
\text { Not in Union }\end{array}$ & $\begin{array}{l}101(95.2 \%) \\
5(4.8 \%)\end{array}$ & $\begin{array}{l}152(74.1 \%) \\
53(25.9 \%)\end{array}$ & $\begin{array}{l}7.04(2.72,18.22) \\
1\end{array}$ & $<0.001$ \\
\hline Religion & $\begin{array}{l}\text { Christians } \\
\text { Muslim }\end{array}$ & $\begin{array}{l}39(36.8 \%) \\
67(63.2 \%)\end{array}$ & $\begin{array}{l}104(50.7 \%) \\
101(49.3 \%)\end{array}$ & $\begin{array}{l}1.76(1.09,2.86) \\
1\end{array}$ & 0.02 \\
\hline Ethnicity & $\begin{array}{l}\text { Oromo } \\
\text { Amhara } \\
\text { Others }\end{array}$ & $\begin{array}{l}75(70.7 \%) \\
22(20.8 \%) \\
9(8.5 \%)\end{array}$ & $\begin{array}{l}127(61.9 \%) \\
42(20.5 \%) \\
36(17.6 \%)\end{array}$ & $\begin{array}{l}1 \\
0.88(0.49,1.59) \\
0.42(0.19,0.92\end{array}$ & $\begin{array}{l}0.690 \\
0.032\end{array}$ \\
\hline
\end{tabular}


Table 2 Behavioral characteristics of diabetic patients who follow at Jimma University medical center, Ethiopia, 2018

\begin{tabular}{|c|c|c|c|c|c|}
\hline Variable & Category & $\begin{array}{l}\text { Cases } \\
(n=106)\end{array}$ & $\begin{array}{l}\text { Controls } \\
(n=205)\end{array}$ & $\operatorname{COR}(95 \% \mathrm{Cl})$ & $P$-Value \\
\hline Adherence to exercise & $\begin{array}{l}\text { Yes } \\
\text { No }\end{array}$ & $\begin{array}{l}59(55.6 \%) \\
47(44.4 \%)\end{array}$ & $\begin{array}{l}130(63.4 \%) \\
75(36.6 \%)\end{array}$ & $\begin{array}{l}1 \\
1.38(0.85,2.22)\end{array}$ & 0.185 \\
\hline Alcoholic history & $\begin{array}{l}\text { Yes } \\
\text { No }\end{array}$ & $\begin{array}{l}16(15 \%) \\
90(85 \%)\end{array}$ & $\begin{array}{l}10(4.8 \%) \\
195(95.2 \%)\end{array}$ & $\begin{array}{l}3.46(1.51,7.93) \\
1\end{array}$ & 0.003 \\
\hline Smoking history & $\begin{array}{l}\text { Yes } \\
\text { No }\end{array}$ & $\begin{array}{l}5(4.7 \%) \\
101(95.3 \%)\end{array}$ & $\begin{array}{l}2(0.9 \%) \\
203(99.1 \%)\end{array}$ & $\begin{array}{l}5.02(0.95,26.35) \\
1\end{array}$ & 0.056 \\
\hline Adherence to medication & $\begin{array}{l}\text { Yes } \\
\text { No }\end{array}$ & $\begin{array}{l}41(38.6 \%) \\
65(61.4 \%)\end{array}$ & $\begin{array}{l}113(55.1 \%) \\
92(44.9 \%)\end{array}$ & $\begin{array}{l}1 \\
1.94(1.20,3.14)\end{array}$ & 0.006 \\
\hline Adherence to meal & $\begin{array}{l}\text { Yes } \\
\text { No }\end{array}$ & $\begin{array}{l}38(35.8 \%) \\
68(64.2 \%)\end{array}$ & $\begin{array}{l}129(62.9 \%) \\
76(37.1 \%)\end{array}$ & $\begin{array}{l}1 \\
3.03(1.86,4.94)\end{array}$ & $<0.001$ \\
\hline Adherence to blood glucose & $\begin{array}{l}\text { Yes } \\
\text { No }\end{array}$ & $\begin{array}{l}62(58.5 \%) \\
44(41.5 \%)\end{array}$ & $\begin{array}{l}166(80.9 \%) \\
39(19.1 \%)\end{array}$ & $\begin{array}{l}1 \\
3.02(1.79,5.08)\end{array}$ & $<0.001$ \\
\hline
\end{tabular}

COR: Crude Odds Ratio, Cl: Confidence Interval, 1: reference group

\section{Determinants of diabetic retinopathy}

In a multiple logistic regression analysis; age 60 years and above, lower educational level (illiterate), poor adherence to medication, family history of Diabetes Mellitus, presence of other micro vascular complication, poor glycemic control, systolic hypertension, poor cholesterol level and being anemic patients were significantly associated with the development of diabetic retinopathy.

The odds of developing Diabetic retinopathy were almost five times higher in patients with age 60 years and above than patients under 60 years of age $(\mathrm{AOR}=5.04$ : $95 \% \mathrm{CI} ; 1.83,13.87)$. The study revealed that illiterate diabetic patients had about seven times higher odds of developing diabetic retinopathy than literates $(\mathrm{AOR}=$ 7.17, 95\%: CI 2.61, 19.70). Patients who did not adhere to medication were three times more likely to develop DR than diabetic patients who did not adhere to medication ( $\mathrm{AOR}=3$; 95\%CI: $1.29,6.95)$. The study also revealed that the odds of developing DR were more than three times higher for patients with baseline Systolic Blood Pressure level of $140 \mathrm{mmHg}$ and above than their counters parts (AOR: 3.38, 95\%CI: 1.26, 9.05). The odds of developing DR were nine times higher in diabetic patients with poor blood glucose control than diabetic patients in good blood glucose control (AOR: 9.08, 95\%CI: 3.7, 22.29).

The study also revealed that participants who had a family history of DM and who had other micro-vascular complications were about four times higher odds of developing $\mathrm{DR}$ than their counterparts $(\mathrm{AOR}=3.95$; 95\%CI: $1.64,9.54),(\mathrm{AOR}=3.76$; 95\%CI: $1.33,10.66)$ respectively. In the study, patients with poor cholesterol levels were about $79 \%$ times less likely to develop DR than diabetic patients who had a good serum cholesterol

Table 3 Medical history of diabetic patients who follow at Jimma University medical center, Ethiopia, 2018

\begin{tabular}{|c|c|c|c|c|c|}
\hline Variable & Category & $\begin{array}{l}\text { Cases } \\
(n=106)\end{array}$ & $\begin{array}{l}\text { Control } \\
(n=205)\end{array}$ & $\mathrm{COR}(95 \% \mathrm{Cl})$ & $P$-Value \\
\hline Family history of DM & $\begin{array}{l}\text { Yes } \\
\text { No }\end{array}$ & $\begin{array}{l}56(52.8 \%) \\
50(47.2 \%)\end{array}$ & $\begin{array}{l}64(31.2 \%) \\
141(68.8 \%)\end{array}$ & $\begin{array}{l}2.46(1.52,3.99) \\
1\end{array}$ & $<0.001$ \\
\hline Duration of DM after diagnosis & $\begin{array}{l}<6 \text { years } \\
\geq 6 \text { years }\end{array}$ & $\begin{array}{l}36(33.9 \%) \\
70(66.1 \%)\end{array}$ & $\begin{array}{l}142(69.2 \%) \\
63(30.8 \%)\end{array}$ & $\begin{array}{l}1 \\
4.38(2.65,7.22)\end{array}$ & $<0.001$ \\
\hline Other micro-vascular complications & $\begin{array}{l}\text { Yes } \\
\text { No }\end{array}$ & $\begin{array}{l}51(48.1 \%) \\
55(51.9 \%)\end{array}$ & $\begin{array}{l}20(9.7 \%) \\
185(90.3 \%)\end{array}$ & $\begin{array}{l}8.57(4.71,15.60) \\
1\end{array}$ & $<0.001$ \\
\hline Systolic blood pressure & $\begin{array}{l}<140 \mathrm{mmHg} \\
\geq 140 \mathrm{mmhg}\end{array}$ & $\begin{array}{l}65(61.3 \%) \\
41(38.7 \%)\end{array}$ & $\begin{array}{l}186(90.7 \%) \\
19(9.3 \%)\end{array}$ & $\begin{array}{l}1 \\
6.17(3.34,11.39)\end{array}$ & $<0.001$ \\
\hline Diastolic blood pressure & $\begin{array}{l}<90 \mathrm{mmhg} \\
\geq 90 \mathrm{mmhg}\end{array}$ & $\begin{array}{l}57(53.7 \%) \\
49(46.3 \%)\end{array}$ & $\begin{array}{l}158(77 \%) \\
47(23 \%)\end{array}$ & $\begin{array}{l}1 \\
2.89(1.75,4.77)\end{array}$ & $<0.001$ \\
\hline Glycaemic level (RBS) & $\begin{array}{l}\text { Good } \\
\text { Poor }\end{array}$ & $\begin{array}{l}39(36.8 \%) \\
67(63.2 \%)\end{array}$ & $\begin{array}{l}164(80 \%) \\
41(20 \%)\end{array}$ & $\begin{array}{l}1 \\
6.87(4.07,11.58)\end{array}$ & $<0.001$ \\
\hline Serum Cholesterol level & $\begin{array}{l}\text { Good } \\
\text { Poor }\end{array}$ & $\begin{array}{l}54(56.2 \%) \\
42(43.8 \%)\end{array}$ & $\begin{array}{l}51(27.1 \%) \\
137(72.9 \%)\end{array}$ & $\begin{array}{l}1 \\
0.29(0.17,0.48)\end{array}$ & $<0.001$ \\
\hline Haemoglobin level & $\begin{array}{l}<11 \mathrm{mg} / \mathrm{dl} \\
\geq 11 \mathrm{mg} / \mathrm{ml}\end{array}$ & $\begin{array}{l}34(32.4 \%) \\
71(67.6 \%)\end{array}$ & $\begin{array}{l}18(8.7 \%) \\
187(91.3 \%)\end{array}$ & $\begin{array}{l}4.97(2.64,9.37) \\
1\end{array}$ & $<0.001$ \\
\hline $\mathrm{BMI}$ & $\begin{array}{l}<25 \mathrm{~kg} / \mathrm{m}^{2} \\
\geq 25 \mathrm{~kg} / \mathrm{m}^{2}\end{array}$ & $\begin{array}{l}76(71.7 \%) \\
30(28.3 \%)\end{array}$ & $\begin{array}{l}146(71.2 \%) \\
59(28.8 \%)\end{array}$ & $\begin{array}{l}1 \\
0.97(0.58,1.64)\end{array}$ & 0.929 \\
\hline
\end{tabular}


level $(\mathrm{AOR}=0.21,95 \% \mathrm{CI}: 0.08,0.514)$. Diabetic patients who were anemic were more than two and half have times the odds of developing DR than their counterparts $(\mathrm{AOR}=2.8,95 \% \mathrm{CI}: 1.05,7.47)($ Table 4$)$.

\section{Discussion}

This study revealed that participants whose age were 60 years and above were five times odds of developing diabetic retinopathy when compared with patients whose age was less than 60 years. Similar findings were reported in various countries. According to the cohort study done in Arbaminch General hospital [13], the possibility of developing DR was almost seven times higher among patients who were 60 and above years than their counterparts. A study from England [5], Armenia [21] and United States [22] also showed that older age was strongly associated with the occurrence of diabetic retinopathy. The study from Oman also indicated that the retinopathy rate was higher in age 60 years and above than their counterparts [23]. As being older age was a strong risk factor for DR, developing any retinopathy was higher in older age [15]. The primary reason for this is that many elderly diabetic patients suffer from physical and mental ailments and often take poor control of their blood sugar especially in consideration of their social background [24].

Illiterate diabetic patients had seven times higher odds of developing DR than literate patients. Studies conducted in Saudi Arabia [25], Korea [26] and Sudan [18] suggest that less educated or who had no formal education had a high probability of developing DR than who attained higher classes. Another finding from Tokyo suggests that lack of proper educational attainment was significantly associated with the progression of retinopathy [27]. The study done in Korean population revealed that illiterate patients had a high probability of developing diabetic complications like DR [28]. Providing proper health information and counseling on the consequences of poor adherence to diabetic care improves the clinical outcomes of diabetic patients [29].

A diabetic who were poorly adherent to diabetic medication was three times odds of DR than diabetic patients who were good adherent. This finding is consistent with studies done in rural India, Armenia and Sudan as poor adherence to medication had significant association with the development of diabetic retinopathy $[18,19,30]$.

This study showed that the odds of developing DR were higher in diabetic patients with a family history of diabetes. This is similar to studies conducted in Arbaminch [13] and China [31]. Finding from Southwest of Ethiopia showed diabetic patients who had family history diabetes were three-times more susceptible to the development of micro vascular complications like DR [12]. Diabetic patients who had poor glycemic control had higher odds of developing retinopathy than those with good glycemic control. Similarly, the studies done in Arbaminch [13], Saudi Arabia [10], China [32], Singapore [33], and Qatar [34] also reported as Diabetic patients with poor glycemic control had a high probability of developing diabetic retinopathy.

This study revealed poor cholesterol control was negatively associated with the occurrence of DR. This finding is similar with the study done in Singapore which reported that higher cholesterol levels were protective of

Table 4 Multivariate logistic regression analysis of Diabetic Retinopathy in Jimma University Medical Center, Ethiopia, 2018

\begin{tabular}{|c|c|c|c|c|c|c|}
\hline Variable & Category & $\begin{array}{l}\text { Cases } \\
(n=106)\end{array}$ & $\begin{array}{l}\text { Control } \\
(n=205)\end{array}$ & COR $(95 \% \mathrm{Cl})$ & $\mathrm{AOR}(95 \% \mathrm{Cl})$ & $P$-Value \\
\hline$\overline{\text { Age }}$ & $\begin{array}{l}<60 \text { years } \\
\geq 60 \text { years }\end{array}$ & $\begin{array}{l}48(45.3 \%) \\
58(54.7 \%)\end{array}$ & $\begin{array}{l}177(86.3 \%) \\
28(13.7 \%)\end{array}$ & $\begin{array}{l}1 \\
7.63(4.39,13.27)\end{array}$ & $\begin{array}{l}1 \\
5.04(1.83,13.87)\end{array}$ & 0.002 \\
\hline Education level & $\begin{array}{l}\text { Illiterate } \\
\text { Literate }\end{array}$ & $\begin{array}{l}43(40.6 \%) \\
63(59.4 \%)\end{array}$ & $\begin{array}{l}25(12.2 \%) \\
180(87.8 \%)\end{array}$ & $\begin{array}{l}4.91(2.77,8.69) \\
1\end{array}$ & $\begin{array}{l}7.17(2.61,19.70) \\
1\end{array}$ & $<0.001$ \\
\hline Adherence to medication & $\begin{array}{l}\text { Yes } \\
\text { No }\end{array}$ & $\begin{array}{l}41(38.6 \%) \\
65(61.4 \%)\end{array}$ & $\begin{array}{l}113(55.1 \%) \\
92(44.9 \%)\end{array}$ & $\begin{array}{l}1 \\
1.94(1.20,3.14)\end{array}$ & $\begin{array}{l}1 \\
3(1.29,6.95)\end{array}$ & 0.01 \\
\hline Family history of DM & $\begin{array}{l}\text { Yes } \\
\text { No }\end{array}$ & $\begin{array}{l}56(52.8 \%) \\
50(47.2 \%)\end{array}$ & $\begin{array}{l}64(31.2 \%) \\
141(68.8 \%)\end{array}$ & $\begin{array}{l}2.46(1.52,3.99) \\
1\end{array}$ & $\begin{array}{l}3.95(1.64,9.54) \\
1\end{array}$ & 0.002 \\
\hline Other micro-vascular complications & $\begin{array}{l}\text { Yes } \\
\text { No }\end{array}$ & $\begin{array}{l}51(48.1 \%) \\
55(51.9 \%)\end{array}$ & $\begin{array}{l}20(9.7 \%) \\
185(90.3 \%)\end{array}$ & $\begin{array}{l}8.57(4.71,15.60) \\
1\end{array}$ & $\begin{array}{l}3.76(1.33,10.66) \\
1\end{array}$ & 0.013 \\
\hline Systolic blood pressure & $\begin{array}{l}<140 \mathrm{mmhg} \\
\geq 140 \mathrm{mmhg}\end{array}$ & $\begin{array}{l}65(61.3 \%) \\
41(38.7 \%)\end{array}$ & $\begin{array}{l}186(90.7 \%) \\
19(9.3 \%)\end{array}$ & $\begin{array}{l}1 \\
6.17(3.34,11.39)\end{array}$ & $\begin{array}{l}1 \\
3.38(1.26,9.05)\end{array}$ & 0.015 \\
\hline Glycaemic level (RBS) & $\begin{array}{l}\text { Good } \\
\text { Poor }\end{array}$ & $\begin{array}{l}39(36.8 \%) \\
67(63.2 \%)\end{array}$ & $\begin{array}{l}164(80 \%) \\
41(20 \%)\end{array}$ & $\begin{array}{l}1 \\
6.87(4.07,11.58)\end{array}$ & $\begin{array}{l}1 \\
9.08(3.70,22.29)\end{array}$ & $<0.001$ \\
\hline Serum Cholesterol level & $\begin{array}{l}\text { Good } \\
\text { Poor }\end{array}$ & $\begin{array}{l}54(56.2 \%) \\
42(43.8 \%)\end{array}$ & $\begin{array}{l}51(27.1 \%) \\
137(72.9 \%)\end{array}$ & $\begin{array}{l}1 \\
0.29(0.17,0.48)\end{array}$ & $\begin{array}{l}1 \\
0.21(0.08,0.514)\end{array}$ & 0.001 \\
\hline Haemoglobin level & $\begin{array}{l}<11 \mathrm{mg} / \mathrm{dl} \\
\geq 11 \mathrm{mg} / \mathrm{ml}\end{array}$ & $\begin{array}{l}34(32.4 \%) \\
71(67.6 \%)\end{array}$ & $\begin{array}{l}18(8.7 \%) \\
187(91.3 \%)\end{array}$ & $\begin{array}{l}4.97(2.64,9.37) \\
1\end{array}$ & $\begin{array}{l}2.8(1.05,7.47) \\
1\end{array}$ & 0.038 \\
\hline
\end{tabular}


any retinopathy [35]. However, the study done in Saudi Arabia [10], China [15] and Malawi [36] revealed that poor control of cholesterol increases the probability of DR their counterparts.

In this study diabetic patients who were with systolic hypertension (Systolic Blood Pressure greater than 140 $\mathrm{mm} \mathrm{hg)} \mathrm{was} \mathrm{also} \mathrm{one} \mathrm{independent} \mathrm{factor} \mathrm{that} \mathrm{determines}$ the development of DR among diabetic patients. Similar findings were also reported in China [15], Arbaminch [14], Korea [28] and in rural India [37].

This study revealed the presence of other micro vascular complication was another determinant of diabetic retinopathy. The finding is consistent with the study done in high-risk China population [30] that revealed renal problem was one of the risk factors associated with DR. Therefore, patients who had history or diagnosed as having any other micro vascular complication like diabetic nephropathy and cardiac diseases had higher odds of developing diabetic retinopathy [28]. Being anemic had also contributed to the occurrence of diabetic retinopathy among diabetic patients. Similar studies in Singapore [33], San Franscisco [38] and India [29] indicated that diabetic patients who were anemic was independently associated with an increased risk of developing DR. But cohort study done in china [15], Korea [28] and Ethiopia [12] suggested that higher hemoglobin was independently associated with an increased risk of DR. These differences could be anemia induced retinal hypoxia which alters angiogenesis, capillary permeability, vasomotor response, and cell survival and also due to low plasma ferritin concentration [11]. Those researchers who considered high hemoglobin leads DR considers that diabetic patients with poor glycemic control have high hemoglobin (plasma ferritin concentration) significantly predicted major micro vascular complications like DR which in turn damages retinal blood vessels [12].

The limitations of this study were behavioral variables like adherence to diabetic care, blood pressure, cholesterol, and hemoglobin level, were collected from patient records. These data may not show the measurements prior to the development of DR. On the other hand, the possibility of information bias especially on alcohol consumption history, smoking history, adherence to diabetic care and wide confidence of random blood glucose control could affect the validity of and precision of the study. Even though measurement for weight and height were taken by health professionals, a single measurement may not be accurate, measurement bias could affect this study.

\section{Conclusion}

The findings in this study shows that older age of 60 years and above, lack of proper educational, poor adherence to anti DM medication, being born from having family history of DM, presence of other microvascular complication like renal problem and heart diseases, poor blood glycemic control level, having systolic hypertension, poor serum cholesterol level and being anemic patients were significantly associated with the development of diabetic retinopathy. Therefore, there is a need to give attention by supplying necessary logistics, assigning trained health professionals and necessary training for who lacks proper trainings for different health professionals who could treat diabetic patients. Similarly, there is a need to consider older age patients, and creating good awareness to have optimal adherence to medication, especially for illiterate patients. Moreover, early identification and prompt management of patients with other micro-vascular complications are vital. Patients adherence to physicians' advice and provided medication is also crucial.

\section{Supplementary information}

Supplementary information accompanies this paper at https://doi.org/10. 1186/s12889-020-08652-2.

Additional file 1. Questionnaire to assess determinants of Diabetic Retinopathy

\section{Abbreviations \\ AOR: Adjusted Odds Ratio; BMI: Body Mass Index; BP: Blood Pressure; DBP: Diastolic Blood Pressure; DM: Diabetic Mellitus; DR: Diabetic Retinopathy; FBS: Fasting Blood Sugar; IGR: Impaired Glucose Regulation; SBP: Systolic Blood Pressure}

\section{Acknowledgments}

We would like to thank Jimma University Institute of Health for financial support for the realization of this finding. We are also grateful for Jimma University Medical Center for the provision of the needed data for our study. Special thanks and appreciation to all those who agreed to participate in this study, mainly respondents, data collectors, and supervisors.

\section{Authors' contributions}

DG involved in the conception, designing methods, analysis, interpretation, and drafting of the manuscript. $\mathrm{HM}$ and DH Participated in designing, data analysis, interpretation of the findings and write-up of the findings. All authors have read and approved the manuscript.

\section{Funding}

This research was funded by Jimma University Institute of Health. The funding body had no any role in the design of the study and collection, analysis, and interpretation of data and in writing the manuscript.

\section{Availability of data and materials}

Data will be available upon request from the corresponding author.

\section{Ethics approval and consent to participate}

Ethical approval was obtained from Jimma University Institute of Health Institutional Review Board before its commencement. The aim of the study was explained and informed written consent was obtained from the study participants. Permission letter was obtained of Jimma University medical center medical director for getting the necessary information, record reviewing and interviewing concerned individuals resides in Hospital.

Consent for publication

Not applicable. 


\section{Competing interests}

The authors declare that they have no competing interests.

\section{Author details}

${ }^{1}$ Nekemte College of Health Sciences, Nekemte, Ethiopia. ${ }^{2}$ Department of Epidemiology, Institute of Health, Jimma University, Jimma, Ethiopia.

Received: 30 July 2019 Accepted: 3 April 2020

Published online: 15 April 2020

\section{References}

1. Wolniewicz, M. Proczka, A. Trzcinski, A. Ramotowska T. Diabetic retinopathy - risk factors, pathogenesis, diagnosis and treatment. MED tube Science. Mar, 2017, Vol. V (1), 26-29

2. Solomon SD, Chew E, Duh EJ, et al. Diabetic retinopathy: a position statement by the American Diabetes Association. Diabetes Care. 2017;40(3): 412-8. https://doi.org/10.2337/dc16-2641.

3. International Council of Ophthalmology. Guidelines for Diabetic Eye Care. Updated 2017. Page 1-40.http://www.icoph.org/downloads/ ICOGuidelinesforDiabeticEyeCare.pdf.

4. World Health Organization. Global status report on NCDC 2014. Geneva: WHO; 2014. https://www.who.int/nmh/publications/ncd-status-report-2014/ en/. Accessed 2 June 2018.

5. Mathur R, Bhaskaran K, Edwards E, et al. Population trends in the 10-year incidence and prevalence of diabetic retinopathy in the UK: a cohort study in the clinical practice research Datalink 2004-2014. BMJ Open. 2017;7: e014444. https://doi.org/10.1136/bmjopen-2016-014444.

6. Yau JWY, Rogers SL, Kawasaki R, Lamoureux EL, Kowalski JW, Bek T, et al. Global prevalence and major risk factors of diabetic retinopathy. Diabetes Care. 2012;35(3):556-64.

7. World Health Organization. Global Initiative for the Elimination of Avoidable Blindness: action plan 2006-2011. Geneva: World Health Organization; 2007. http://www.who.int/iris/handle/10665/43754. Accessed 26 May 2018.

8. Clinical Practice guidlines. Screening of diabetic retinopathy. 2011. Available from: http://www.moh.gov.my. Accessed 26 May 2018.

9. Galsworthy P. Ethiopia LEOPARD (Lion's Ethiopian ophthalmic Programme against retinal disease and Diabets) project Paul Galsworthy joint Programme manager- BSBC DESP; 2014.

10. Khan AR, Wiseberg JA, Lateef ZA, Khan SA. Prevalence and determinants of diabetic retinopathy in Al hasa region of Saudi Arabia: primary health care Centre based cross-sectional survey, 2007-2009. Middle East Afr J Ophthalmol. 2010;17(3):257-63. https://doi.org/10.4103/0974-9233.65502.

11. Karoli R, Fatima J, Shukla V, Garg P, Ali A. Predictors of diabetic retinopathy in patients with type 2 diabetes who have normoalbuminuria. Ann Med Health Sci Res. 2013;3(4):536-40. https://doi.org/10.4103/2141-9248.122087.

12. Tilahun AN, Waktola C, Tewodros GM, Sadik GT, Amare DW, et al. Major micro vascular complications and associated risk factors among diabetic outpatients in Southwest Ethiopia. Endocrinol Metab Syndr. 2017;6(4):272. https://doi.org/10.4172/2161-1017.1000272.

13. Chisha $Y$, Terefe $W$, Assefa $H$. Incidence and factors associated with diabetic retinopathy among diabetic patients at arbaminch general hospital, Gamo gofa Zone (longitudinal follow up data analysis). J Diabetol [serial online] 2017 [cited 2019 Jan 19];8:1-6. Available from: http://www. journalofdiabetology.org/text.asp?2017/8/1/1/205982.

14. Chisha Y, Terefe W, Assefa H, Lakew S (2017) Prevalence and factors associated with diabetic retinopathy among diabetic patients at Arbaminch general hospital, Ethiopia: cross sectional study. PLoS One 12(3): e0171987. https://doi.org/https://doi.org/10.1371/journal.pone.0171987.

15. Liu L, Wu J, Yue S, et al. Incidence Density and Risk Factors of Diabetic Retinopathy Within Type 2 Diabetes: A Five-Year Cohort Study in China (Report 1). Int J Environ Res Public Health. 2015;12(7):7899-7909. Published 2015 Jul 10. doi:https://doi.org/10.3390/ijerph120707899.

16. World Health Organization. NAURU NCD Risk Factors STEPS Report. West pacific. 2007. file:///C:/Users/TOSHIBA/Downloads/Nauru_NCD_rpt.pdf.

17. International diabets Federation. Global guideline for type 2 diabetes. 2012. www.idf.org. Accessed 30 June 2018.

18. Elwali ES, Almobarak AO, Hassan MA, Mahmooud AA, Awadalla H, Ahmed $\mathrm{MH}$. Frequency of diabetic retinopathy and associated risk factors in Khartoum, Sudan: population based study. Int J Ophthalmol. 2017;10(6):948954. Published 2017 Jun 18. doi:https://doi.org/10.18240/ijo.2017.06.18.
19. Vislisel J, Oetting TA. Diabetic retinopathy: from one medical student to another. EyeRounds.org. 2010. Available from: http://www.EyeRounds.org/ tutorials/diabetic-retinopathy-med-students. Accessed 29 May 2018.

20. World Health Organization. A training manual for health workers on healthy life style: An approach for the prevention and control of Noncommunicable diseases. 2009. Geneva.

21. Giloyan A, Harutyunyan T, Petrosyan V. The prevalence of and major risk factors associated with diabetic retinopathy in Gegharkunik province of Armenia : cross-sectional study. BMC Ophthalmol. 2015;15:1-7. https://doi. org/10.1186/s12886-015-0032-0.

22. Wang SY, Andrews CA, Herman WH, Gardner TW, Stein JD. Incidence and risk factors for developing diabetic retinopathy among youths with type 1 or type 2 diabetes throughout the United States. Ophthalmology 2016;124(4):424-430. http://dx.doi.org/https://doi.org/10.1016/j.ophtha.2016.10.031.

23. Khandekar R, Al Lawatii J, Mohammed AJ, Al RA. Diabetic retinopathy in Oman: a hospital based study. Br J Ophthalmol. 2003;87(9):1061-4.

24. Bin-Bin He, Li Wei, Yun-Juan Gu, et al., Factors Associated with Diabetic Retinopathy in Chinese Patients with Type 2 Diabetes Mellitus. International Journal of Endocrinology. vol. 2012, Article ID 157940, 8 pages, 2012. https://doi.org/https://doi.org/10.1155/2012/157940.

25. Almalki NR, Almalki TM, Alswat K. Diabetics retinopathy knowledge and awareness assessment among the type 2 diabetics. Open Access Maced J Med Sci. 2018;6(3):574-7. https://doi.org/10.3889/oamjms.2018.121.

26. Lee Y-H (2018) Socioeconomic differences among community-dwelling diabetic adults screened for diabetic retinopathy and nephropathy: the 2015 Korean community health survey. PLoS One 13(1): e0191496. https:// doi.org/https://doi.org/10.1371/journal.pone.0191496.

27. Emoto N, Okajima F, Sugihara H, Goto R. A socioeconomic and behavioral survey of patients with difficult-to-control type 2 diabetes mellitus reveals an association between diabetic retinopathy and educational attainment. Patient Prefer Adherence. 2016;10:2151-62. https://doi.org/10.2147/PPA. S116198.

28. Kim YJ, Kim JG, Lee JY, et al. Development and progression of diabetic retinopathy and associated risk factors in Korean patients with type 2 diabetes: the experience of a tertiary center. J Korean Med Sci. 2014;29(12): 1699-705. https://doi.org/10.3346/jkms.2014.29.12.1699.

29. Schillinger D, Grumbach K, Piette J, et al. Association of Health Literacy with Diabetes Outcomes. JAMA.2002;288(4):475-482. doi:https://doi.org/10.1001/ jama.288.4.475.

30. Wang J, Zhang RY, Chen RP, et al. Prevalence and risk factors for diabetic retinopathy in a high-risk Chinese population. BMC Public Health. 2013; 13: 633. Published 2013 Jul 5. doi:https://doi.org/10.1186/1471-2458-13-633.

31. S. Alemu, A. Dessie, A. Tsegaw, C.C. Patterson, E.H.O. Parry, D.I.W. Phillips, E.R. Trimble, Retinopathy in type 1 diabetes mellitus: major differences between rural and urban dwellers in Northwest Ethiopia, diabetes research and clinical practice. 2015. http://dx.doi.org/https://doi.org/10.1016/j.diabres. 2015.04.010.

32. Tien Y Wong, Ning Cheung, Wan Ting Tay, Jie Jin Wang, Tin Aung, Seang Mei Saw, Su Chi Lim, E Shyong Tai, Paul Mitchell. Prevalence and risk factors for diabetic retinopathy: the Singapore Malay eye study. Ophthalmology. 2008; 115 (11). 1869-1875. https://doi.org/https://doi.org/10.1016/j.ophtha. 2008.05.014

33. Shu D, Ting W, Ophth M, Chui G, Cheung M. Review diabetic retinopathy : global prevalence, major risk factors, screening practices and public health challenges : a review. Clin Exp Ophthalmol. 2016;44:260-77. https://doi.org/ 10.1111/ceo.12696.

34. Elshafei M, Gamra H, Khandekar R, Al Hashimi M, Pai A, Ahmed MF. Prevalence and determinants of diabetic retinopathy among persons $\geq 40$ years of age with diabetes in Qatar: a community-based survey. Eur J Ophthalmol 2011;21(1):39-47. PMID: 20602322.

35. Stamler J, Daviglus ML, Garside DB, Dyer AR, Greenland P, Neaton JD. Relationship of baseline serum cholesterol levels in 3 large cohorts of younger men to long-term coronary, cardiovascular, and all-cause mortality and to longevity. JAMA. 2000;284(3):311-8. https://doi.org/10.1001/jama.284.3.311.

36. Beare NAV, Msukwa G, Burgess PI, Allain TJ, Garc M. Research : complications high prevalence in Malawi of sight-threatening retinopathy and visual impairment caused by diabetes: identification of populationspecific targets for intervention. Diab Med. 2014;31(12):1643-50.

37. Raman R, Ganesan S, Pal SS, et al. Prevalence and risk factors for diabetic retinopathy in rural India. Sankara Nethralaya Diabetic Retinopathy Epidemiology and Molecular Genetic Study III (SN-DREAMS III), report no 2. 
BMJ Open Diabetes Res Care. 2014;2:e000005. https://doi.org/10.1136/ bmjdrc-2013-000005.

38. Shah K, Gandhi A, Natarajan S. Diabetic retinopathy awareness and associations with multiple comorbidities: insights from DIAMOND study. Indian J Endocrinol Metab. 2018;22(1):30-5. https://doi.org/10.4103/ijem. IJEM_240_17.

\section{Publisher's Note}

Springer Nature remains neutral with regard to jurisdictional claims in published maps and institutional affiliations.

Ready to submit your research? Choose BMC and benefit from:

- fast, convenient online submission

- thorough peer review by experienced researchers in your field

- rapid publication on acceptance

- support for research data, including large and complex data types

- gold Open Access which fosters wider collaboration and increased citations

- maximum visibility for your research: over $100 \mathrm{M}$ website views per year

At BMC, research is always in progress.

Learn more biomedcentral.com/submissions 